International Journal of Instruction e-ISSN: 1308-1470 • www.e-iji.net

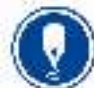

Article submission code: 20201110093143
Received: 10/11/2020

Revision: 13/02/2021
July $2021 \bullet$ Vol.14, No.3

p-ISSN: 1694-609X

pp. 1025-1042

Accepted: 09/03/2021

OnlineFirst: 24/06/2021

\title{
The Effect of a Flipped Classroom with Communicative Language Teaching Approach on Undergraduate Students' English Speaking Ability
}

\section{Marady Phoeun}

M.Ed., Faculty of Education, Naresuan University, Thailand, mardipmd@gmail.com

\section{Supanee Sengsri}

Assoc.Prof., Faculty of Education, Naresuan University, Thailand, supanees@nu.ac.th

\begin{abstract}
This research investigates whether a flipped classroom with Communicative Language Teaching (CLT) approach can lead students to increased gains in speaking skills within an undergraduate English class at the Royal University of Phnom Penh, Cambodia. This was designed to utilize pre-class online videos to replace live "chalk and talk" lectures, with a variety of CLT activities implemented during class time, including discussion-based learning, pair and group work, role play, and games. A mixed method was used to analyze different sources of data, including pre- and post-tests on speaking, written one of grammar and vocabulary, and observations. The experiment was employed with 21 freshmen of an academic year of 2017-2018 $(n=21)$ to determine any differences in their speaking achievements that might be associated with a flipped classroom and CLT. The results from the observations and pre and post tests indicated that the participants not only enhanced their speaking ability but also changed their attiutde toward learning English. These results specified that the flipped instruction with the CLT activities were effective in improving the participants' speaking ability which significantly contributed to better learning outcomes. Therefore, it is recommended that English language teachers in Cambodia consider implementing a flipped classroom and CLT approach in their classrooms.
\end{abstract}

Keywords: communicative language teaching, flipped classroom, speaking ability, undergraduate students, language teaching

\section{INTRODUCTION}

English language has been a universal language for more than a century and has been recognized in numerous nations around the globe. Likewise in Cambodia, English has expanded its importance with the conviction that it is vital for social development and change. Throughout the last twenty years, the eminence of English has advanced from that of a foreign language that isn't used by Cambodians inside the nation to a language gradually employed inside the nation (Igawa, 2008). For educational purposes, the ability of English provides students a chance to take up scholarship, to fulfil their school

Citation: Phoeun, M., \& Sengsri, S. (2021). The Effect of a Flipped Classroom with Communicative Language Teaching Approach on Undergraduate Students' English Speaking Ability. International Journal of Instruction, 14(3), 1025-1042. https://doi.org/10.29333/iji.2021.14360a 
requirements, to pass placement tests at colleges, and to join local or international symposiums. For social purposes, it enables individuals to get remunerative jobs with businesses oversea, NGOs, or international organizations, to get an opportunity for an occupation advancement, and to benefit from day-to-day entertainment, for examples, watching television, listening to the radio, or perusing books in English (Mao, 2014). Hence, instruction of English is perceived as fundamental abilities that will be significant for the future success of this nation (Igawa, 2008).

Even though there are a lot of Cambodian people learning English all over the country, it is still a challenging task for most of the students when it comes to speaking English. Shumin (2002) stated that speaking is perceived as the most intricate language skill for foreign language learners at all time. A research from Chamnan (2017) on "analytical study of English speaking skills of Cambodian students" demonstrated that some of the main causes of English speaking problems of Cambodian students were students' English environment, their motivation, students 'lacking of time to speak English and teacher's teaching techniques. Many teachers still use a traditional method such as Grammar Translation which students act as passive learners and teachers spend most of the time in class lecturing.

Owing to the need to improve the speaking ability of students, lots of approaches, techniques, and strategies have been employed and investigated and found that Communicative Language Teaching (CLT) is one of the most efficient and effective ways in aiding students to achieve their speaking and communicative goals (Richards, 2006). CLT is a method that suggests that language learning ought to be done in a significant setting with authentic language as the input. As stated by Lindsay and Knight (2006), the CLT approach focuses on the reality that language is learned so as to communicate effectively throughout life in a meaningful way, without the constraints of form and structure. In other words, CLT gives more focus on meaning rather than structure; and students practice to communicate in the language through numerous kinds of communicative activities, such as role-plays, dialogues, games and problem-solving activities. One of the most common principles of CLT is authentic use of the language in the whole task settings.

In the 21 st century, technology is seen as an essential component of educational settings (Basal, 2015). The prospects offered by technologies in education are limitless, so lots of instructors are trying to find techniques to integrate it into their classrooms in order to build a good learning environment for students (Koehler et al., 2004). With all of the technologies available, educators aim to provide greater learning experiences and a more appealing and exciting classroom atmosphere (Basal, 2015). Adopted by many technological channels, a video is one of the most effective teaching tools when used correctly (Hartsell \& Yuen, 2006; Shephard, 2003). One technique for integrating technology such as videos for teaching is called a flipped or an inverted classroom.

Based on Bergmann \& Sams (2012), a flipped classroom could be defined as a setting that is customarily done in class is as of now done at home and that is generally done as homework is now completed in class. To simplify, it is when a long lecture in class is moved to online videos or digital materials, whereas a huge amount of time in the 
classroom is consumed on meaningful and deep learning. This allows a deeper learning activities during class time, which means learners are given more occasions to engage in meaningful tasks, and therefore improving the learning results. (Baker, 2000; Boucher et al., 2013; Lage \& Treglia, 2000; Pinnelli \& Fiorucci, 2015; Subramaniam, 2016). The implementation of a flipped model in an English classroom helped students engage more in English speaking activities and therefore enhance their speaking ability (Abdullah et al., 2019; Cetin Köroğlu and Çakır, 2017).

Given the current situation in Cambodia in regards to the demand of English communication, English speaking problem and advantages offered by CLT and a flipped classroom, this study seeks to investigate whether a flipped classroom with Communicative Language Teaching (CLT) approach can lead students to increased gains in speaking skills within an undergraduate English class at the Royal University of Phnom Penh, Cambodia.

\section{Review Literature}

\section{English Education in Cambodia}

Since the Paris Peace Accord in 1991, there has been a great change in Cambodian society in overall. The appearance of the United Nations Transitional Authority in Cambodia, recognized as UNTAC, has irrefutably made Cambodian individuals view English as a universally significant language. One factor that has been leading to the necessities of English is the existence of NGOs and international aid organizations whose basic language is English. Furthermore, those in the administration unit likewise needs to speak with benefactors and other foreign associations, which practically utilize English as their official language. This requires all levels of the household specialists to learn English to work with those operators. Beside these reasons, the government needs to speak with the ASEAN nations, every one of whom utilize English as their mode of correspondence (Clayton, 2007). Moreover, Cambodian individuals are unequivocally persuaded that any person who can communicate in English will have a productive opportunity to secure great positions, hence making a lot of money to help their living. This reason has strived a great number of people to begin learning English; and subsequently, the number of classes, schools, institutions and colleges have rapidly started to expand throughout the country. English has gotten well known among Cambodian students from that point onward (Mao, 2014).

\section{Communicative Language Teaching (CLT)}

Definition of Communicative Language Teaching

CLT can be defined as a list of ideas about the aims of language teaching on how learners acquire a language, the varieties of classroom activities that best assist learning, and the roles of instructors and learners in the classroom. As in Ozsevik's study, the idea of communicative competence is viewed as the major concept of CLT, which incorporates recognizing what to state and how to state it suitably depending on the circumstances, the participants, and their roles and purposes (as cited in Abahussian, 2016). Harmer (2001) identified two features of CLT which are "what to teach" and 
"how to teach". The "what to teach" of this approach is more significant on language roles than on structures. The second feature, "how to teach", proposes that interaction in a class should engage meaningful activities that offer opportunities for actual practice to improve learners' knowledge and skills (Abahussain, 2016).

Ahmad and Rao (2013) conducted a study to make an evaluation on an employment of a CLT approach in instructing English in schools of Pakistan which have long used the Grammar Translation Method (GTM). The results from the study indicated that there was a significant difference between the two means which explained that the experimental group performed better than the control group after the treatment for a quarter of a year. The study showed that, with the provision of appropriate conditions, a superior classroom environment, and a well-trained and dynamic educators with a decent comprehension of English, utilizing CLT to facilitate instruction could prompt more noteworthy outcomes than educating through traditional method. This demonstrates that the CLT approach is progressively appropriate for teaching English as a foreign language than the Grammar Translation Method (GTM). In addition, Sarfraz et al. (2015) studied the perceptions of both teachers and students of CLT in the Computer Assisted Language Learning environment. Feedback of communicative language activities and questionnaire were used to get the data, with the results showing positive perceptions of all students and teachers towards the CLT approach. What is more, Azadi et al. (2015) examined the impact of classroom interaction in improving learners' speaking skills. The study discovered that the communication learners had in the class helped enhance their speaking ability. The researchers also recommended that dedicating a few hours of a class time for students to associate with one another and rousing them to have significant discussions would prompt a more communicative setting. Ochoa et al. (2016) investigated the association between activities of CLT and their impact on learners' inspiration to learn English. The results demonstrated that learners found CLT activities to be motivating. In addition, they felt more motivated once engaging with communicative exercises as those helped them improve their fluency, pronunciation, and performance when utilizing English for correspondence. Activities such as games, role plays, pair and group work, and presentation made them feel more confident when interacting with one another. Similarly, Wajid and Saleem (2017) did a research to discover points of view of students at King Abdul-Aziz University in order to estimate their conformity attitude and its level on the application of CLT. The results showed that students displayed attitudes of conformity towards enhancing their speaking ability through CLT activities. Also, the students demonstrated a significant level of conformity with respect to executing CLT in English classroom. Hence, this investigation can be viewed as a proof of the adequacy of CLT for improving students' speaking skills.

\section{Classroom activities in Communicative Language Teaching Approach}

According to Abahussain (2016), activities utilized in CLT are categorized into two crucial clusters - Pre-communicative activities and Communicative activities. Precommunicative activities stress on practicing elements of a language in an isolation so that learners can be fluent in linguistic system and the capacity to create suitable 
language as opposed to just communication of meaning. Nevertheless, communicative activities need students to use and implement their pre-communicative information and skills for actual communicating meanings. Littlewood \& William (1981), in addition, dispensed these activities into two subgroups: functional communication activities, for example problem-solving and information-gap activities; and social interaction activities, for instance simulation and role-playing, demanding students 'creative mind in a circumstance or adopting a particular role to carry on as needs to be. Likewise, Richards (2005) suggested some activities to use in CLT. Those are as followings:

Information-gap activities: it describes the setting where people communicate to get and receive the information which they do not own. This is known as an information-gap. More authentic communication is expected to arise in the classroom if learners extend their linguistic and communicative language practice to acquire the information.

Jig-saw activities: Usually the class is separated into teams and each team has some pieces of data required to complete an activity. The class has to put the pieces together to complete the whole. To make this activity possible, students need to use their language assets to interact meaningfully and hence grasp meaningful and communicative practice.

Task-completion activities: The purpose of this activity is to utilize one's language assets to finish an activity. Some of examples of the activity are puzzles, games, mapreading and so forth.

Information gathering activities: This activity requires learners to conduct surveys, interview and search in which they need to use their linguistic assets to gather data.

Opinion-sharing activities: Students share and compare their point of view, philosophies and values in this activity.

Information-transfer activities: Students are required to take data that is given in one structure, and tell it in an alternative structure.

Reasoning gap activities: These activities include descending some new data from given data through the procedure of interpretation, practical reasoning and so forth.

Role play: In this activity, learner are given roles and make up a scene based on information or clues provided.

Emphasis on pair work and group work: Activities mentioned above reveal an essential feature of classroom activities in CLT, specifically that they are intended to be done in pairs or small groups.

\section{Flipped Classroom}

Definition of a flipped classroom

The concept of "flipped classroom" was originated from America and initially coined by Baker (2000) and Lage et al. (2000). It refers to restructuring the inside and outside classroom practice in actual teaching tasks and puts the teaching importance on 
motivating students' autonomous learning interest and exploring ability (Dong, 2016). By giving a reversed model of teaching, the flipped classroom turned into one in which learners could involve more with the class activities in a collaborative manner as opposed to simply listening to lectures during class time (Baker, 2000; Lage et al., 2000). It is an approach in which learners take control of their learning and this leads to an increased amount of time for interaction between students and teachers (Bergmann \& Sams, 2012; Subramaniam, 2016). The flipped classroom also offers a priority to pupils where all of them are engaged with their learning and the instructor turns into the "guide on the side" and not the "sage on the stage" as described by Baker (2000). The flipped classroom approach is sure a way to support autonomic learning as students can watch the recordings whenever and wherever before going to a class (Subramaniam, 2016). By offering the lecture videos for learners to view at home, teachers have more time in class to have students combine what they have learned and to engage them in problem-solving and task-based assignments, letting instructors check with learners if they can understand and apply new information and concepts or not. Every time instructors find out that learners do not understand any point or concept, they can intrude straightaway and help learners on an individual basis (Doman \& Webb, 2017).

Research by Chen Hsieh et al. (2017) conducted a study on learning English idioms by flipped learning, using the LINE application, and by conventional instruction. The results revealed that the participants' motivation has been developed as they were more active in using idioms in class, while at the same time they improved their idiomatic knowledge. This showed that flipped learning was effective in achieving the instructional aims of the class. Another research conducted to compare two English composition courses with Japanese university students. One course was taught following a flipped classroom concept while the other was done traditionally. The findings demonstrated that the students who learned under the flipped method spent more time preparing for their class and could produce a lot more words in the post compositions written test. Also, the flipped classroom resulted in significantly better enhancements in the students' writing proficiency (Leis et al., 2015). Besides, Çetin Köroğlu and Çakır (2017) studied whether a flipped classroom model could enhance the speaking skills of the students. The study was conducted by using pre-test and post-test to see the different results of both experimental and control groups. From the results obtained, it was found out that the participants in the experimental group advanced their fluency, coherence, lexical resource, and grammar, pronunciation, and accuracy skills considerably. Li (2016), on the other hand, examined students 'satisfaction towards the employment of a flipped classroom model in college oral English teaching. He discovered that students were happy with the implementation, particularly in the comprehensive improvement and language use. The participants in the study agreed that the flipped class helped them better their speaking ability.

\section{METHOD}

This section comprises of two parts; the initial part reports research objective, while the second one details the research design that comprises of the subject, the research instruments, data collection and data analysis. 


\section{Research Objective}

This research is conducted to investigate the effect of a flipped classroom with CLT approach on English speaking ability of undergraduate students in Cambodia.

\section{Research Design}

This research adopted a mixed method which include the one group pre-test/post-test of speaking and written one of grammar and vocabulary, and teacher's observation. The achievement of the pre- and post-tests were measured and compared with each other.

The subject: The sample was selected purposively considering students' level of English proficiency administered by Royal University of Phnom Penh in Cambodia. Twenty one freshmen of academic year 2017-2018 of pre-intermediate level at Royal University of Phnom Penh in Cambodia were the sample for the study.

\section{Instrument}

Lesson Plan: In this research, the lesson plan was the key instrument to be developed. To fulfill its objectives, nine lesson plans covering two hours by each lesson were developed under the topics of "What's up", and "Impressions" from the course book "Touch Stone 3". Lesson plans were developed based on flipped classroom model and CLT approach. In order to make sure that lesson plans were done correctly based on the approaches, the researcher also had the lesson plans verified by five experts who have in-depth knowledge of a flipped classroom and CLT approach.

Video clips: videos were selected from YouTube. However, in a few lessons, the researcher had to produce new videos to support the lessons.

To select videos, the researcher used ASSURE model as shown below

A (Analyze): The first step in the ASSURE model, the researcher analyzed the learners 'general characteristics, competencies and learning styles with the content of the video.

$\mathrm{S}$ (State Objective): The second step, the researcher stated objectives by looking at the content of "What's up" and "Impressions" units.

S (Select): During the third step, the researcher selected the suitable videos by looking at the objectives of each lesson.

$\mathrm{U}$ (Utilize): Fourth step, the researcher utilized the videos by integrating into the lesson plans.

$\mathrm{R}$ (Require Learner Participation): The fifth step, the researcher selected the videos which "Require learner participation". The researcher planned how learners would take part in the learning processes.

E (Evaluate): Finally, the researcher evaluated the video clips whether they fulfilled the objectives or not (Kurt, 2015).

As suggested by Smaldino et al. (2008), in order to produce videos, the researcher followed three main steps. First the researcher planed what information to be distributed 
in particular units to the students. Secondly, division of the plan for each unit was followed. Lastly, the researcher checked whether the video clips matched the objectives or not. After the production of the videos, the researcher had the videos checked by three experts who have in-depth knowledge of ICT.

Achievement Tests: The tests were divided into two parts. The first part was an oral test while the second one was a written test of grammar and vocabulary.

The first part of the test was to assess the ability of speaking skills. In order to check students' English speaking ability, the researcher used rubric score for the assessment. The total score on the speaking rubric was 25. (Appendix A) It had five parts such as fluency, pronunciation, vocabulary, grammar, and comprehensibility (adapted from Latifa et al., 2015).

The second part was the thirty items Multiple Choice Questions (MCQ) with four possible options were developed, followed by another thirty items of gap completion; this part mainly checked students' knowledge about grammar and vocabulary before and after learning through flipped classroom with CLT approach. Each of the item was given 1 ; therefore, the total score of this test was 60 . The researcher decided to include grammar and vocabulary as a part of the test because speaking ability also involves the use of form, structure, and vocabulary. Based on Husnu (2018), the entirety of the cycle in instructing should have the option to ascent of students' grammar and vocabulary because without these basic skills, students couldn't communicate in English easily. Those with awful vocabulary and sentence structure are generally not prepared to get practice to talk; they would dodge to practice English.

Teacher's observation: the researcher observed both in-class and online activities so as to investigate the interaction between participants, their learning behavior, and their speaking development.

Online platform: Among many online platforms, the researcher decided to use social media, specifically Facebook, to deliver the contents of the lessons to the students; and it is also a place where students and teacher communicated, shared and discussed the lessons online. Social networking sites such as Facebook, Twitter, Instagram, Edmodo, Blackboard, and YouTube have demonstrated to give a positive effect on learning and teaching as learners are effortlessly involved to the technology, making the sites as among the famous learning tools (Tazijan et al., 2016). The researcher chose Facebook as an online platform for the flipped classroom in this research because it is the number one popular social media site in Cambodia, which has 4.8 million people registered and 2.9 million use it daily; and noticeably, among those numbers, 690000 people are university students (The Development of Cambodia's Social Media and Digital Science, 2017).

\section{Steps of implementing the flipped classroom with CLT in lesson plans}

The teacher created one private group in Facebook and added all the participants in the group. The group was set as a closed group because the teacher only wanted the sample groups to post, share and see things in the group. Before class, the teacher posted lecture 
videos in Facebook group, and asked students to complete some tasks. Sentence completion, voice and video recordings were the main tasks which were usually done online. During the class time, the teacher devoted most of in-class time for CLT activities. The teacher utilized the initial 10 minutes for a quiz to check if the students really watch or read the materials provided, and additional 15 minutes for checking the guided worksheets and explaining and answering questions students have about the language points, and the remaining time for aforementioned activities. Some of the most done activities were discussion-based, pair and group work, role play, presentation, and educational games. Those activities were engaging, collaborating and communitive. After each session of the class, the teacher reflected what she had done and took note of what was going wrong in the class to better for the next class. If necessary, some homework was provided to students to follow up what they had learned.

\section{Data Collection and Analysis}

After having developed all the research instruments, the data were collected as the following:

Testing: In order to fulfill the objective of the research, before and after treating students for eighteen hours with researcher's developed lesson plans on a flipped classroom with CLT approach on teaching English speaking skills, one time pre-test and post-test were administered respectively to the selected sample group, freshmen of pre-intermediate level of Royal University of Phnom Penh, Cambodia.

Observation: The teacher observed each session and took note of what went wrong or well went well in the class, and improved for the next class. Since the researcher is the one who taught the class herself, she could only make little note. However, she has recorded videos of each session. Hence, after each class she watched the videos and took note of challenges, difficulties, students' behaviors, and students' learning progress.

Pre- and post-test scores from achievement tests were analyzed by using an application software, Statistical Package for the Social Sciences (SPSS). It was used to conduct a basic analysis of the means, standard deviations, and a dependent $t$-test of the data.

\section{FINDINGS}

After data collection, a basic analysis of the means, standard deviations, and a dependent $t$-Test of the data was conducted. The results of the current study are presented in accordance with the research question.

RQ: To what extend does a flipped classroom with CLT approach have on the English speaking ability of undergraduate students in Cambodia?

Descriptive statistics comparing the pre- and post-tests of speaking in the flipped classroom with CLT indicated that the mean score of the post-test $(M=15.66)$ was higher than that of the pre-test $(M=12.66)$. Similarly, the result from a pre- and postwriting test for grammar and vocabulary showed that the mean score of the post-test $(M=51.95)$ was also higher than that of the pre-test $(M=42.71)$ (See Table 1). 
Table 1

Descriptive statistics of pair samples

\begin{tabular}{cllll}
\hline Pair Sample statistics & Mean & n & Std. Deviation & Std. Error \\
\hline Pair 1: Speaking Post-Test & 15.666 & 21 & 3.198 & 0.698 \\
Speaking Pre-Test & 12.666 & 21 & 3.651 & 0.796 \\
\hline Pair 2: Writing Post-Test & 51.952 & 21 & 4.080 & 0.890 \\
Writing Pre-Test & 42.714 & 21 & 6.309 & 1.376 \\
\hline
\end{tabular}

These data were subjected to the $t$-Test for paired samples, with the results showing a statistically significant gain $(\mathrm{t}=6.55, \mathrm{n}=21, \mathrm{p}=0.00)$ for speaking test, and $(\mathrm{t}=7.82$, $\mathrm{n}=21, \mathrm{p}=0.00$ ) for writing test (See Table 2).

The Paired-Samples $t$-Test shown in Table 2 indicated that with the use of the flipped classroom and CLT, the participants performed significantly better on the post-test ( $p<$ .05) compared to the pre-test.

Table 2

The paired-sample t-Test

\begin{tabular}{llllll}
\hline Paired Sample Test & Mean & Std. Deviation & $\mathrm{n}$ & $\mathrm{t}$ & P-Value \\
\hline $\begin{array}{l}\text { Pair1: } \\
\text { Speaking post-test } \\
\text { Speaking Pre-Test }\end{array}$ & 3.000 & 2.097 & 21 & 6.554 & 0.000 \\
\hline $\begin{array}{l}\text { Pair 2: } \\
\begin{array}{l}\text { Writing Post-Test } \\
\text { Writing Pre-Test }\end{array}\end{array}$ & 9.238 & 5.412 & 21 & 7.822 & 0.000 \\
\hline
\end{tabular}

Data from the observation are presented in two perspectives as the followings:

\section{a. Students' learning behaviors}

At the beginning, most students felt unhappy to involve in activities proposed by the teacher. During the online activities, only a few students did the tasks assigned. Many of the students did not do and did not dare to tell the teacher their problem or reason they did not do the tasks. However, most of them followed the in-class activities which the teacher asked them to do. It came to a surprise when many of students did not know how to work with one another. Most importantly, it was hard for them when they worked with whom they rarely or never talked to. In this classroom context, students were from different departments and faculties; they only came for English class twice a week and their previous learning environment was not encouraging in term of cooperation and interaction. As a result, students did not know and were not close to one another. Moreover, some students were naturally shy to talk to new people; they only talked to those they knew or sat nearby. Though they have been learning with one another for almost one whole year, interaction among each other was still absent. At the first three sessions, some students were hesitated to talk to their group members and were very shy to express themselves; while some tried to avoid the speaking activities. The researcher noticed that some were shaking while coming to the front of the class for presentation. Many other students felt pressured when asked to talk in English. After three sessions, there were some changes in term of behaviors and reaction to the new teaching method. 
Some students started to get used to activities both on-line and in-class as they involved more in activities designed by the teacher. Most importantly, they started to enjoy the learning English.

\section{b. Students' English development}

For the last three sessions, it was found out that most students have built their confidence gradually in speaking English and doing things. Some smart students showed lots of improvement in their speaking skills, specifically on fluency. Some other students also paid more attention on accuracy when they talk and express themselves. Some tried to apply what had learnt in their speaking. The research noticed that many students were braver to discuss and share ideas with their classmates, and with the whole class. Their nervousness seemed to reduce, though, to some students, not much. Most students were used to the new way of learning; they were satisfied with what were provided. However, there were few students who seem to improve very little in term of confidence or speaking ability. They still had lots of pauses and stuck to produce words or sentences; and they were not very active in group or pair discussion. This can be because of their natural shyness or unwillingness to open up to new things.

Quantitative findings indicated that the flipped classroom with CLT had significant effects on students' English skills specifically in speaking and basic skills of grammar and vocabulary; while the qualitative data specified that the students learning behavior has been changed and their learning performance has been enhanced. This finding suggested that quantitative and qualitative data support each other.

\section{DISCUSSION}

With the use of flipped classroom combined with CLT approach, undergraduate students significantly improved their English skills. In this study, we conducted two different kinds of tests which are speaking and written tests of grammar and vocabulary. The Pre- and post-tests of writing indicated that the mean score of the post-test was higher than that of the pre-test. The mean differences of the speaking and writing test showed that there was a wide range of scores between the pre- and post-tests of writing in the flipped instruction than that in the speaking test. This suggested that the participants improved more in terms of grammar and vocabulary, rather than their speaking skills from the flipped design and CLT. This could be because students were not used to speaking English in class before; the experiment period was the first time they got to speak in English. Furthermore, the intervention of the study lasted for just 18 hours, which was quite short for speaking skill to be improved a lot. If the study went on for at least a semester and involved instructing students more than twice a week using CLT activities, better outcomes might be achieved. As Ochoa et al. (2016) suggested in their investigation, if educators utilize CLT activities on different occasions in the class, learners will have more chances to use English in the classroom.

According to the observation, the researcher noticed that the students were reluctant to cope with the flipped classroom and CLT approach. What is more, when it came to pair or group work, many of them did not know how to work with one another. This was possibly the students had not been taught to work cooperatively with one another and to 
be passive without any response as a result of traditional teaching method; however, after some sessions, students started to get used to activities both on-line and in-class. Many of them were willing to do activities assigned by the teacher and started to use English to express their opinions in group discussion and presentation. This could happen because of many factors, and one of which is the flipped learning concept that was adopted in this study. As in the flipped class, the lecture videos, with the option of being viewed and watched by students at their own pace and as many times as they need give an instructional setting more in tune with the individual differences, such as their different learning styles (Afrilyasanti et al., 2016; Cohen, 2012; Dörnyei, 2005; Mayer \& Moreno, 2003). It spares more opportunities for communicative exercises among learners or between the educator and learners, and class time can be utilized more fruitfully and inventively (Fulton, 2012). The participants in this study had more time in the class to practice the target language and did the communicative tasks as the traditional lectures were moved to the online platform; and therefore, their speaking skill has been improved. This finding is similar to that of Amiryousefi, 2019; Chen Hsieh et al., 2017; Li, 2016; Li \& Suwanthep, 2017, who discovered that the flipped classroom assisted students to increase scores on an English speaking test.

However, the flipped classroom alone would not help the participants to develop their speaking skills if there was no appropriate teaching approach implemented. CLT in this study played an important role in making the students' speaking skills enhanced. Since the activities involved pair and group works most of the time, this gave them chances to talk, share, and express themselves, which for some time made them get used it and therefore built up their confidence (Sakarkaya, 2013). With CLT approach, the learners in this study were given opportunities to practice and utilize English in true circumstances (Boonkit, 2010; Ochoa et al., 2016). They were not passive anymore; they had been changed into dynamic, communitarian students who utilized the materials accessible to associate with their friends and the teacher in English. The students would learn grammar, vocabulary and reading as their traditional classroom; in CLT, however, those skills were transformed into speaking by communicative activities. Students no longer learnt the skills differently; they had to use the basic skills of grammar and vocabulary to apply it in authentic situations which the teacher had prepared for them (Richards, 2006). From the results obtained, the CLT activities were found to have enhanced English speaking ability of the participants, and this is in line with Algonhaim 2014; Azadi et al., 2015; Saputra, 2015; Wajid \& Saleem, 2017; Wu, 2010, who found CLT to be effective in the development of students' speaking skills.

\section{CONCLUSION AND RECOMMDATIONS}

This research study aimed to examine the effect of a flipped classroom with Communicative Language Teaching (CLT) approach on aspects of the students' English speaking ability at Royal University of Phnom Penh (RUPP), Cambodia. The results from the study indicated that, students significantly improved their English speaking skills as they were able to expose to authentic and communicative activities in the classroom and in the online platform. Their behavior toward learning English has been gradually changed as well, from passive learners who would just sit and listen to lectures 
to active ones. Therefore, it is recommended that teachers of English in Cambodia consider using CLT approach and a flipped classroom concept in their classrooms if they face difficulty in teaching speaking skills and time shortage in practice the language. Other researchers who wish to conduct the same or similar study in the future should do it in a longer period of time, with a large number of students, and with other institutes or universities to check if this can create a bigger impact on students' speaking skills.

\section{REFERENCES}

Abahussain, M. O. (2016). Implementing Communicative Language Teaching Method in Saudi Arabia: Challenges Faced by Formative Year Teachers in State Schools.

Abdullah, M. Y., Hussin, S., \& Ismail, K. (2019). Implementation of Flipped Classroom Model and Its Effectiveness on English Speaking Performance. International Journal of Emerging Technologies in Learning (iJET), 14(09), 130-147.

Afrilyasanti, R., Cahyono, B. Y., \& Astuti, U. P. (2016). Effect of flipped classroom model on Indonesian EFL students' writing ability across and individual differences in learning. International Journal of English Language and Linguistics Research, 4(5), $65-81$.

Alghonaim, A. (2014). Saudi university students' perceptions and attitudes towards Communicative and non-Communicative Activities and their relationship to Foreign Language anxiety. Research Journal of English Language and Literature, 2(2).

Ahmad, S., \& Rao, C. (2013). Applying Communicative Approach in Teaching English as a Foreign Language: a Case Study of Pakistaner. Porta Linguarum: revista internacional de didáctica de las lenguas extranjeras, (20), 187-203.

Amiryousefi, M. (2019). The incorporation of flipped learning into conventional classes to enhance EFL learners' L2 speaking, L2 listening, and engagement. Innovation in Language Learning and Teaching, 13(2), 147-161.

Azadi, S., Aliakbari, M., \& Azizifar, A. (2015). The role of classroom interaction on improvement of speaking among Iranian EFL learners. International Journal of Language Learning and Applied Linguistics World, 8(1), 126-135.

Baker, W. (2000). The" Classroom Flip": Using Web Course Management Tools to Become the Guide by the Side.(pp. 9-17). Cedarville University: Communication Faculty Publication.

Basal, A. (2015). The implementation of a flipped classroom in foreign language teaching. Turkish Online Journal of Distance Education, 16(4), 28-37.

Bergmann, J., \& Sams, A. (2012). Flip your classroom: Reach every student in every class every day: International Society for Technology in Education. 
Boonkit, K. (2010). Enhancing the development of speaking skills for non-native speakers of English. Procedia-social and behavioral sciences, 2(2), 1305-1309. https://doi.org/10.1016/j.sbspro.2010.03.191

Boucher, B., Robertson, E., Wainner, R., \& Sanders, B. (2013). "Flipping” Texas State University's physical therapist musculoskeletal curriculum: Implementation of a hybrid learning model. Journal of Physical Therapy Education, 27(3), 72-77.

Çetin Köroğlu, Z., \& Çakır, A. (2017). Implementation of flipped instruction in language classrooms: An alternative way to develop speaking skills of pre-service English language teachers. International Journal of Education and Development Using Information and Communication Technology, 13(2), 42- 55.

Chamnan, V. T. (2017). An analytical study of english speaking skills of cambodian students of preah Sihanouk Raja Buddhist University Battambang Branch.

Chen Hsieh, J. S., Wu, W.-C. V., \& Marek, M. W. (2017). Using the flipped classroom to enhance EFL learning. Computer Assisted Language Learning, 30(1-2), 1-21.

Clayton, T. (2007). Transition, culture, and language in Cambodia. In A.B.M. Tsui, \& J.W.

Cohen, A. D. (2012). Strategies: The interface of styles, strategies, and motivation on tasks. In S. Mercer, R. Stephen, \& M. Williams (Eds.), Psychology for language learning: Insights from research, theory and practice (pp. 136-150). Basingstoke, England: Palgrave Macmillan.

Doman, E., \& Webb, M. (2017). The Flipped Experience for Chinese University Students Studying English as a Foreign Language. TESOL Journal, 8(1), 102-141. doi: 10.1002/tesj.264

Dong, X. (2016). Application of Flipped Classroom in College English Teaching. Creative Education, 7(09), 1335.

Dornyei, Z. (2005). The psychology of the language learner: Individual differences in second language acquisition. New Jersey: Mahwah.

Fulton, K. (2012). Upside down and inside out: Flip your classroom to improve student learning. Learning \& Leading with Technology, 39(8), 12-17.

Harmer, J. (2001). The Practice of English language teaching (3rd ed.). Harlow: Pearson Education Limited.

Hartsell, T., \& Yuen, S. (2006). Video streaming in online learning. AACE Journal, 14(1), 3143 . 
Husnu, M. (2018). Demonstration Technique to Improve Vocabulary and Grammar Element in Teaching Speaking at EFL Learners. English Language Teaching, 11(2), 2630 .

Igawa, K. (2008). English language and its education in Cambodia, a country in transition. Shitennoji University Bulletin, 46(1), 343-369.

Koehler, M. J., Mishra, P., Hershey, K., \& Peruski, L. (2004). With a Little Help From Your Students: A New Model for Faculty Development and Online Course Design. Journal of Technology and Teacher Education, 12(1), 25-55.

Kurt, S. (2015). ASSURE: Instructional Design Model. Retrieved from https://educationaltechnology.net/assure-instructional-design-model/

Lage, M., Platt, G., \& Treglia, M. (2000). Inverting the classroom: A gateway to creating an inclusive learning environment. Journal of Economic Education, 31(1), 30 43. doi:10.1080/00220480009596759

Latifa, A., Rahman, A., Hamra, A., Jabu, B., \& Nur, R. a. (2015). Developing a Practical Rating Rubric of Speaking Test for University Students of English in Parepare, Indonesia. English Language Teaching, 8(6), 166-177.

Leis, A., Cooke, S., \& Tohei, A. (2015). The effects of flipped classrooms on English composition writing in an EFL environment. International Journal of ComputerAssisted Language Learning and Teaching (IJCALLT), 5(4), 37-51.

Li, S. (2016). A study of learners' satisfaction towards college oral English flipped classroom. Theory and Practice in Language Studies, 6(10), 1958-1963.

Li, S., \& Suwanthep, J. (2017). Integration of Flipped Classroom Model for EFL Speaking. International Journal of Learning and Teaching. doi: 10.18178/ijlt.3.2.118123

Lindsay, C. and Knight, P. (2006) Learning and Teaching English. Oxford: OUP.

Littlewood, W., \& William, L. (1981). Communicative language teaching: An introduction: Cambridge University Press.

Mao, S. (2014) Education and Policy on English Language in Cambodia: Ministry of Education, Youth, and Sport (MoEYS) Education Strategic Plan (ESP) Cambodia, Phnom Penh

Mayer, R. E., \& Moreno, R. (2003). Nine ways to reduce cognitive load in multimedia learning. Educational Psychologist, 38(1), 43-52. https://doi.org/10.1207/S15326985EP3801_6 
Ochoa, C., Cabrera, P., Quiñónez, A., Castillo, L., \& González, P. (2016). The effect of communicative activities on efl learners' motivation: A case of students in the amazon region of Ecuador. Colombian Applied Linguistics Journal, 18(2), 39-48.

Pinnelli, S., \& Fiorucci, A. (2015). University and Flipped Learning TIC \& DIL Project: Framework and Design. International Association for Development of the Information Society.

Richards, J. C. (2005). Communicative language teaching today: SEAMEO Regional Language Centre.

Richard, Jack C. (2006). Communicative Language Teaching Today. New York: Cambridge University Press.

Sakarkaya, V. (2013). 12 Pair and group work activities: Keep them or leave them?. Teacher-researchers in acTion, 163.

Saputra, J. B. (2015). Communicative Language Teaching: Changing Students' Speaking Skill. Premise: Journal of English Education, 4(1).

Sarfraz, S., Mansoor, Z., \& Tariq, R. (2015). Teachers' and Students' Perceptions of the Communicative Language Teaching Methodology in the CALL Environment: A Case Study. Procedia - Social and Behavioral Sciences, 199, 730-736. doi: 10.1016/j.sbspro.2015.07.604

Shephard, K. (2003) Questioning, promoting and evaluating the use of streaming video to support student learning, British Journal of Educational Technology, 34(3), 297-310.

Shumin, K. (2002). Factors to consider: Developing adult EFL students' speaking abilities. Methodology in language teaching: An anthology of current practice, 12, 204211.

Smaldino, S. E., Lowther, D. L., Russell, J. D., \& Mims, C. (2008). Instructional technology and media for learning.

Subramaniam, S. R. (2016). Concept and Characteristics of Flipped Classroom. International journal of Emerging Trends in Science and Technology. doi: 10.18535/ijetst/v3i10.01

Tazijan, F. N., Baharom, S. S., \& Shaari, A. H. (2016). Building communication skills through flipped classroom. Proceedings of ISELT FBS Universitas Negeri Padang, 4(1), 289-295.

Wajid, M. A., \& Saleem, M. (2017). Learner conformity to Communicative Language Teaching Approach in EFL contexts: A case study in Saudi Arabia. International Journal of Language and Linguistics, 4, 240-249. 
Wu, K. H. (2010). The Relationship between Language Learners' Anxiety and Learning Strategy in the CLT Classrooms. International Education Studies, 3(1), 174-191. https://doi.org/10.5539/ies.v3n1p174 


\section{Appendix A: Scoring Rubrics for Speaking Test}

\begin{tabular}{|c|c|c|c|c|c|}
\hline Score & Fluency & Pronunciation & Grammar & Vocabulary & Content \\
\hline 5 & $\begin{array}{l}\text { - Smooth and fluid } \\
\text { speech } \\
\text { - Few to no } \\
\text { hesitations } \\
\text { - No attempts to } \\
\text { search for words } \\
\text {-Volume is } \\
\text { excellent. }\end{array}$ & $\begin{array}{l}\text { - Pronunciation } \\
\text { is excellent } \\
\text { - Good effort at } \\
\text { accent }\end{array}$ & $\begin{array}{l}\text { Accuracy and } \\
\text { variety of } \\
\text { grammatical } \\
\text { structures }\end{array}$ & $\begin{array}{l}\text { - Excellent } \\
\text { control of } \\
\text { language } \\
\text { features } \\
\text { - A wide range } \\
\text { of well- chosen } \\
\text { vocabulary }\end{array}$ & $\begin{array}{l}\text { Excellent } \\
\text { level of } \\
\text { description } \\
\text { - Additional } \\
\text { details } \\
\text { beyond the } \\
\text { required }\end{array}$ \\
\hline 4 & $\begin{array}{l}\text { - Smooth and fluid } \\
\text { speech } \\
\text { - Few hesitations } \\
\text { - A slight search for } \\
\text { words } \\
\text { - Inaudible word or } \\
\text { two }\end{array}$ & $\begin{array}{l}\text { - Pronunciation } \\
\text { is good } \\
\text { - Good effort at } \\
\text { accent }\end{array}$ & $\begin{array}{l}\text { Some errors in } \\
\text { grammatical } \\
\text { Structures } \\
\text { possibly } \\
\text { caused by } \\
\text { attempt to } \\
\text { include a } \\
\text { variety. }\end{array}$ & $\begin{array}{l}\text { - Good language } \\
\text { control } \\
\text { - Good range of } \\
\text { relatively } \\
\text { well-chosen } \\
\text { vocabulary }\end{array}$ & $\begin{array}{l}\text { - Good level } \\
\text { of } \\
\text { Description } \\
\text { - All required } \\
\text { information } \\
\text { included }\end{array}$ \\
\hline 3 & $\begin{array}{l}\text { - Speech is relatively } \\
\text { Smooth } \\
\text { - Some hesitation } \\
\text { and unevenness } \\
\text { caused } \\
\text { by rephrasing and } \\
\text { searching for words }\end{array}$ & $\begin{array}{l}\text { - Pronunciation } \\
\text { is good } \\
\text { - Some effort at } \\
\text { accent, but is } \\
\text { definitely non- } \\
\text { native }\end{array}$ & $\begin{array}{l}\text { - Frequent } \\
\text { grammatical } \\
\text { errors that do } \\
\text { not } \\
\text { obscure } \\
\text { meaning } \\
\text { - Little variety } \\
\text { in } \\
\text { structures }\end{array}$ & $\begin{array}{l}\text { - Adequate } \\
\text { language } \\
\text { Control } \\
\text { - Vocabulary } \\
\text { range is lacking }\end{array}$ & $\begin{array}{l}\text { - Adequate } \\
\text { description } \\
\text { - Some } \\
\text { additional } \\
\text { details } \\
\text { should be } \\
\text { provided }\end{array}$ \\
\hline 2 & $\begin{array}{l}\text { - Speech is } \\
\text { frequently } \\
\text { hesitant with some } \\
\text { sentences left } \\
\text { uncompleted } \\
\text { - Volume very soft. }\end{array}$ & $\begin{array}{l}\text { - Pronunciation } \\
\text { is okay } \\
\text { - No effort } \\
\text { towards a native } \\
\text { accent }\end{array}$ & $\begin{array}{l}\text { - Frequent } \\
\text { grammatical } \\
\text { errors even in } \\
\text { simple } \\
\text { structures that } \\
\text { at times } \\
\text { obscure } \\
\text { meaning. }\end{array}$ & $\begin{array}{l}\text { - Weak language } \\
\text { control } \\
\text { - Basic } \\
\text { vocabulary } \\
\text { choice with } \\
\text { some words } \\
\text { clearly } \\
\text { lacking }\end{array}$ & $\begin{array}{l}\text { - Description } \\
\text { lacks some } \\
\text { critical } \\
\text { details that } \\
\text { make it } \\
\text { difficult for } \\
\text { the listener to } \\
\text { understand }\end{array}$ \\
\hline 1 & $\begin{array}{l}\text { - Speech is slow, } \\
\text { hesitant \& strained } \\
\text { except for short } \\
\text { memorized phrases } \\
\text { - Difficult to } \\
\text { perceive continuity } \\
\text { in speech } \\
\text { - Inaudible. }\end{array}$ & $\begin{array}{l}\text { - Pronunciation } \\
\text { is lacking and } \\
\text { hard to } \\
\text { understand } \\
\text { - No effort } \\
\text { towards a native } \\
\text { accent }\end{array}$ & $\begin{array}{l}\text { - Frequent } \\
\text { grammatical } \\
\text { errors even in } \\
\text { simple } \\
\text { structures } \\
\text { - Meaning is } \\
\text { obscured. }\end{array}$ & $\begin{array}{l}\text { - Weak language } \\
\text { control } \\
\text { - Vocabulary } \\
\text { that is used does } \\
\text { not match the } \\
\text { task }\end{array}$ & $\begin{array}{l}\text { - Description } \\
\text { is so lacking } \\
\text { that the } \\
\text { listener } \\
\text { cannot } \\
\text { understand }\end{array}$ \\
\hline
\end{tabular}

International Journal of Instruction, July $2021 \bullet$ Vol.14, No.3 